\title{
Penyuluhan Isi Undang-Undang No. 22 Tahun 2009 Tentang Lalulintas Dan Angkutan Jalan
}

\author{
Rohani*, Hasyim, I Wayan Suteja, I Gede Putu Warka, Ida Ayu Oka Suwati Sideman \\ Fakultas Teknik Universitas Mataram, Mataram
}

Kata Kunci: Kecelakaan lalu lintas, UU no 22 th 2009, sepeda motor

\begin{abstract}
Abstrak: Kecelakaan lalu-lintas adalah suatu peristiwa di jalan yang tidak diduga dan tidak disengaja melibatkan kendaraan dengan atau tanpa pengguna jalan lain yang mengakibatkan korban manusia dan/atau kerugian harta benda berdasarkan Undang-Undang No. 22 Tahun 2009. Data dari Polres Lombok Barat menunjukkan bahwa pada tahun 2015 tercatat 305 korban kecelakaan diantaranya 90 orang meninnggal dunia, kemudian pada tahun 2016 jumlah meninggal dunia 93 orang dari 207 korban kecelakaan. Sedangkan menurut data Kementerian Perhubungan selama 2016 terjadi 106.573 kecelakaan lalu lintas di seluruh Indonesia, sebanyak 73,9\% melibatkan sepeda motor. Dirjen Perhubungan Darat Budi Setiyadi Pada tahun 2016, lebih dari 175 ribu sepeda motor mengalami kecelakaan. Korbannya sebagian besar berada pada rentang usia 15-60 tahun. Pelajar pada rentang usia 10-19 tahun menjadi korban kecelakaan urutan kedua. Hal ini menunjukkan bahwa kecelakaan dan pelanggaran yang melibatkan sepeda motor cukup tinggi, yang memberikan indikasi bahwa ketidak-tertiban dari sikap pengendara sepeda motor di ruas jalan yang bahkan cendrung dapat mengganggu kendaraan lain dapat berpotensi untuk menyebabkan kejadian kecelakaan dan pelanggaran lalulintas. Pengguna sepeda motor yang didominasi oleh pengemudi dengan usia 16 - 29 tahun, dan kelompok umur ini kalau kita tilik adalah kelompok remaja, pemuda atau pelajar, sehingga pemuda/ pelajar yang akan diberikan penyuluhan adalah pelajar SMPN I Lembar. Sasaran pelaksanaan kegiatan ini yaitu dengan memberikan penyuluhan isi UU no. 22 tahun 2009 dalam upaya peningkatan kesadaran hukum berlalulintas di jalan raya harus perlu disampaikan agar terbangun peningkatan kesadaran hukum berlalulintas. Dengan demikian pelanggaran dalam berkendaraan di jalan raya yang berdampak pada kecelakaan dapat diminimalisir di wilayah Kabupaten Lombok Barat.
\end{abstract}

Korspodensi email: rohani@unram.ac.id

\section{PENDAHULUAN}

Menurut Undang-Undang No. 22 Tahun 2009 tentang Lalu-lintas dan Angkutan Jalan, kecelakaan lalu-lintas adalah suatu peristiwa di jalan yang tidak diduga dan tidak disengaja melibatkan kendaraan dengan atau tanpa pengguna jalan lain yang mengakibatkan korban manusia dan/atau kerugian harta benda.

Berdasarkan data dari Polres Lombok Barat, terlihat bahwa pada tahun 2015 tercatat 305 korban kecelakaan diantaranya 90 orang meninnggal dunia, kemudian pada tahun 2016 jumlah meninggal dunia 93 orang dari 207 korban kecelakaan. Sedangkan menurut data Kementerian Perhubungan selama 2016 terjadi 106.573 kecelakaan lalu lintas di seluruh Indonesia, sebanyak 73,9\% melibatkan sepeda motor. Dirjen Perhubungan Darat Budi Setiyadi Pada tahun 2016, lebih dari 175 ribu sepeda motor mengalami kecelakaan. Korbannya sebagian besar berada pada rentang usia 15-60 tahun. Pelajar pada rentang usia 10-19 tahun menjadi korban kecelakaan urutan kedua.

Kecelakaan yang melibatkan sepeda motor di jalan raya tidak hanya terjadi karena halhal teknis, misalnya tentang seluk beluk motor, tetapi juga karena rendahnya disipin 
pengendara dalam berlalu lintas. Berkelompok di depan garis pembatas putih pada lampu pengatur lalu lintas (traffic light), dan beberapa diantaranya melewati lampu merah bila kesempatan itu ada. Hal-hal tersebut menjadi pemandangan sehari-hari di jalan raya. Belum lagi membelok dimana terdapat rambu-rambu tidak boleh membelok, melawan arus lalu lintas, melawan arah di jalan satu arah, melintas di trotoar yang disediakan bagi pejalan kaki dan melintas di jalur sepeda yang disediakan di jembatan penyebrangan. Selain itu kendati ada kewajiban untuk menggunakan helm, tetapi dengan mudahnya ditemui pengendara motor yang tidak menggunakan helm.

Sementara disisi lain pengetahuan berlalulintas atau berkendaraan yang rendah di jalan raya oleh sebagian besar pengemudi dan kurangnya pengetahuan tentang denda yang akan dikenakan jika terjadi pelanggaran lalu lintas, memberikan kontribusi tertingi akan resiko terjadinya kecelakaan. Berdasarkan beberapa penelitian tentang kecelakaan di Kabupaten Lombok Barat disebutkan bahwa penyebab utama terjadinya kecelakaan adalah a) manusia, b) kendaraan, c) lingkungan jalan raya. Dari beberapa data kejadian kecelakaan yang diinventarisasi kecelakaan di jalan raya didominasi oleh kelompok umur 15-22 tahun, yang apabila kita evaluasi kelompok tersebut adalah kelompok pelajar, mahasiswa dan pemuda. Banyak kecelakaan disebabkan oleh tidak siapnya pengemudi menguasai kendaraannya di jalan raya, tingginya pilihan kecepatan, serta kondisi kendaraan yang tidak sempurna, dimana hal itu banyak disebabkan oleh lemahnya pemahaman pengemudi (pelaku perjalanan) terhadap sign atau tanda-tanda yang diberikan di jalan seperti marka, rambu, dan sebagainya.

Begitu juga dengan tingkat pemahaman yang rendah pada kelompok pelajar terutama pelajar Sekolah Menengah Pertama (SMP), yang ditunjukkan oleh angka kecelakaan yang cukup tinggi yang terjadi di NTB. Oleh karena itu penting untuk dilakukan upaya secara terus menerus dan berkesinambungan oleh semua pihak agar kelompok ini dapat memiliki tingkat kesadaran hukum berlalu lintas di jalan raya dan sangsi yang akan dikenakan jika mereka melakukan pelanggran lalu lintas dengan cara memberikan penyuluhan. Karena itu yang diharapkan dalam penyuluhan ini adalah peningkatan kesadaran hukum berlalu lintas kepada masyarakat khususnya pelajar, mahasiswa, dan muda-mudi penting untuk dilakukan agar tingkat pemahaman kesadaran hukum berlalulintas dapat lebih baik sehingga dapat menjamin keselamatan mereka berlalulintas dan angka kejadian kecelakaan dapat diperkecil.

Berdasarkan Undang-Undang Nomor 22 Tahun 2009 Tentang Lalu Lintas Dan Angkutan Jalan sebagai pengganti Undang-Undang No. 14 Tahun 2009 Tentang Lalu Lintas Dan Angkutan Jalan yang ditertibkan untuk lebih mewujudkan keselamatan, keamanan, dan ketertiban berlalu lintas dan angkutan jalan. Untuk mewujudkan tujuan Undang-Undang tersebut salah satunya dengan mengatur mengenai penegakan hukum melalui penyidikan dan penindakan pelanggaran lalu lintas dan angkutan jalan oleh Kepolisian dan Dinas Perhubungan.

Masalah lalu lintas yang semakin kompleks ini tidak diiringi dengan kesadaran hukum pengendara sepeda motor dalam berlalu lintas, tetapi malah sebaliknya berkurangnya kesadaran hukum pengendara sepeda motor dalam berlalu lintas di jalan raya. Sehingga untuk menekan angka kecelakaan lalu-lintas yang dirasakan sangat tinggi, upaya ke depan diarahkan pada penanggulangan secara komprehensif yang mencakup upaya pembinaan, pencegahan, pengaturan, dan penegakan hukum. Upaya pembinaan tersebut dilakukan 
melalui peningkatan intensitas pendidikan berlalulintas dan penyuluhan hukum serta pembinaan sumber daya manusia.

\section{METODE KEGIATAN}

Kegiatan ini akan dilaksanakan dengan metode penyuluhan. Adapun fasilitas dan peralatan yang diperlukan dalam penyuluhan ini adalah:

- Gambar-gambar tentang tata cara berlalulintas dan pelanggaran lalu lintas terhadap Rambu, Marka dan Fasilitas Lainnya di Jalan Raya dan Persimpangan

- Contoh-contoh berlalulintas yang tertib dan kurang tertib (film atau gambar tentang kejadian kecelakaan)

- Modul-modul sederhana tentang tata cara berlalulintas dijalan raya

\section{HASIL DAN PEMBAHASAN}

Pengabdian yang dilakukan di SMPN I Lembar ini dilakukan dengan cara memberikan penyuluhan isi undang-undang no. 22 tahun 2019 tentang lalu lintas dan angkutan jalan. Isi dari materi yang diberikan pada penyuluhan ini adalah:

\section{Tata Cara Berlalulintas Berdasarkan Undang-Undang Nomor 22 Tahun 2009}

Pasal 105:

Setiap orang yang menggunakan jalan wajib:

a. berperilaku tertib; dan/atau

b. mencegah hal-hal yang dapat merintangi, membahayakan Keamanan dan Keselamatan

Lalu Lintas dan Angkutan Jalan, atau yang dapat menimbulkan kerusakan Jalan.

Pasal 106:

1) Setiap orang yang mengemudikan Kendaraan Bermotor di Jalan wajib mengemudikan kendaraannya dengan wajar dan penuh konsentrasi.

2) Setiap orang yang mengemudikan Kendaraan Bermotor di Jalan wajib mengutamakan keselamatan Pejalan Kaki dan pesepeda.

3) Setiap orang yang mengemudikan Kendaraan Bermotor di Jalan wajib mematuhi ketentuan tentang persyaratan teknis dan laik jalan.

4) Setiap orang yang mengemudikan Kendaraan Bermotor di Jalan wajib mematuhi ketentuan:

a. rambu perintah atau rambu larangan;

b. Marka Jalan

c. Alat Pemberi Isyarat Lalu Lintas;

d. Gerakan lalu lintas

e. Berhenti dan Parkir

5) Pada saat diadakan pemeriksaan Kendaraan Bermotor di Jalan setiap orang yang mengemudikan Kendaraan Bermotor wajib menunjukkan:

a. Surat Tanda Nomor Kendaraan Bermotor atau Surat Tanda Coba Kendaraan Bermotor

b. Surat Izin Mengemudi

c. Bukti lulus uji berkala; dan/atau

d. Tanda bukti lain yang sah. 
6) Setiap orang yang mengemudikan Kendaraan Bermotor beroda empat atau lebih di Jalan dan penumpang yang duduk di sampingnya wajib mengenakan sabuk keselamatan.

7) Setiap orang yang mengemudikan Kendaraan Bermotor beroda empat atau lebih yang tidak dilengkapi dengan rumah-rumah di Jalan dan penumpang yang duduk di sampingnya wajib mengenakan sabuk keselamatan dan mengenakan helm yang memenuhi standar nasional Indonesia.

8) Setiap orang yang mengemudikan Sepeda Motor dan Penumpang Sepeda Motor wajib mengenakan helm yang memenuhi standar nasional Indonesia.

9) Setiap orang yang mengemudikan Sepeda Motor tanpa kereta samping dilarang membawa Penumpang lebih dari 1 (satu) orang.

Pasal 107

1) Pengemudi Kendaraan Bermotor wajib menyalakan lampu utama Kendaraan Bermotor yang digunakan di Jalan pada malam hari dan pada kondisi tertentu.

2) Pengemudi Sepeda Motor selain mematuhi ketentuan sebagaimana dimaksud pada ayat (1) wajib menyalakan lampu utama pada siang hari.

Pasal 108

1) Dalam berlalu lintas Pengguna Jalan harus menggunakan jalur jalan sebelah kiri.

2) Penggunaan jalur jalan sebelah kanan hanya dapat dilakukan jika:

a. Pengemudi bermaksud akan melewati Kendaraan di depannya; atau

b. diperintahkan oleh petugas Kepolisian Negara Republik Indonesia untuk digunakan sementara sebagai jalur kiri.

3) Sepeda Motor, kendaraan bermotor yang kecepatannya lebih rendah, mobil barang, dan Kendaraan Tidak Bermotor berada pada lajur kiri Jalan.

4) Penggunaan lajur sebelah kanan hanya diperuntukkan bagi kendaraan dengan kecepatan lebih tinggi, akan membelok kanan, mengubah arah, atau mendahului kendaraan lain.

Pasal 110

1) Pengemudi yang berpapasan dengan Kendaraan lain dari arah berlawanan pada jalan dua arah yang tidak dipisahkan secara jelas wajib memberikan ruang gerak yang cukup di sebelah kanan Kendaraan.

2) Pengemudi sebagaimana dimaksud pada ayat (1) jika terhalang oleh suatu rintangan atau Pengguna Jalan lain di depannya wajib mendahulukan Kendaraan yang datang dari arah berlawanan.

Pasal 111

Pada jalan yang menanjak atau menurun yang tidak memungkinkan bagi Kendaraan untuk saling berpapasan, Pengemudi Kendaraan yang arahnya menurun wajib memberi kesempatan jalan kepada Kendaraan yang mendaki.

Pasal 112

Pada persimpangan Jalan yang dilengkapi Alat Pemberi Isyarat Lalu Lintas, Pengemudi Kendaraan dilarang langsung berbelok kiri, kecuali ditentukan lain oleh Rambu Lalu Lintas atau Alat Pemberi Isyarat Lalu Lintas.

Pasal 114

Pada perlintasan sebidang antara jalur kereta api dan Jalan, Pengemudi Kendaraan wajib: 
a. berhenti ketika sinyal sudah berbunyi, palang pintu kereta api sudah mulai ditutup, dan/atau ada isyarat lain;

b. mendahulukan kereta api; dan

c. memberikan hak utama kepada kendaraan yang lebih dahulu melintasi rel.

Pasal 115

Pengemudi Kendaraan Bermotor di Jalan dilarang:

a. mengemudikan Kendaraan melebihi batas kecepatan paling tinggi yang diperbolehkan sebagaimana dimaksud dalam Pasal 21; dan/atau

b. berbalapan dengan Kendaran Bermotor lain.

Pasal 116

1) Pengemudi harus memperlambat kendaraannya sesuai dengan Rambu Lalu Lintas.

2) Selain sesuai dengan Rambu Lalu Lintas sebagaimana dimaksud pada ayat (1) Pengemudi harus memperlambat kendaraannya jika:

a. akan melewati Kendaraan Bermotor Umum yang sedang menurunkan dan menaikkan Penumpang;

b. akan melewati kendaraan tidak bermotor yang ditarik oleh hewan, hewan yang ditunggangi, atau hewan yang digiring;

c. cuaca hujan dan/atau genangan air;

d. memasuki pusat kegiatan masyarakat yang belum dinyatakan dengan rambu lalu lintas;

e. mendekati persimpangan atau perlintasan sebidang kereta api; dan/atau

f. melihat dan mengetahui ada Pejalan Kaki yang akan menyeberang.

\section{Denda Pelanggaran Lalu Lintas}

Denda Pelanggaran Lalu Lintas berdasarkan UU Nomor 22 Tahun 2009 Tentang Lalu Lintas Dan Angkutan Jalan

A. Setiap orang yang melakukan perbuatan yang mengakibatkan gangguan pada fungsi Rambu Lalu Lintas, Marka Jalan, Alat Pemberi Isyarat Lalu Lintas, fasilitas Pejalan Kaki, dan alat pengaman Pengguna Jalan, dipidana dengan pidana kurungan paling lama 1 (satu) bulan atau denda paling banyak Rp 250.000,00 (dua ratus lima puluh ribu rupiah).

B. Setiap pengemudi (semua jenis kendaraan bermotor)

1. Tidak membawa Surat Izin Mengemudi (SIM) yang sah pasal 288 ayat (2) jo Pasal 106 ayat (5) huruf b dipidana dengan pidana kurungan paling lama 1 (satu) bulan dan/atau denda paling banyak Rp 250.000,00 (dua ratus lima puluh ribu rupiah).

2. Tidak memiliki SIM

Mengemudikan kendaraan bermotor di jalan, tidak memiliki Surat Izin Mengemudi, Pasal 281 jo Pasal 77 ayat (1) dipidana dengan pidana kurungan paling lama 4 (empat) bulan atau denda paling banyak Rp1.000.000,00 (satu juta rupiah).

3. STNK tidak sah

Kendaraan Bermotor yang tidak dilengkapi dengan Surat Tanda Nomor Kendaraan Bermotor atau Surat Tanda Coba Kendaraan Bermotor yang ditetapkan oleh Kepolisian Negara Republik Indonesia Pasal 288 ayat (1) jo Pasal 106 ayat (5) huruf 
a dipidana dengan pidana kurungan paling lama 2 (dua) bulan atau denda paling banyak Rp 500.000,00 (lima ratus ribu rupiah).

4. Tanda Nomor Kendaraan Bermotor (TNKB)

Kendaraan Bermotor di Jalan yang tidak dipasangi Tanda Nomor Kendaraan Bermotor yang ditetapkan oleh Kepolisian Negara Republik Indonesia. Pasal 280 jo Pasal 68 ayat (1) dipidana dengan pidana kurungan paling lama 2 (dua) bulan atau denda paling banyak Rp 500.000,00 (lima ratus ribu rupiah).

5. Memasang perlengkapan yang dapat mengganggu keselamatan

Setiap orang yang mengemudikan Kendaraan Bermotor di Jalan yang dipasangi perlengkapan yang dapat mengganggu keselamatan berlalu lintas. Pasal 279 jo Pasal 58 dipidana dengan pidana kurungan paling lama 2 (dua) bulan atau denda paling banyak Rp 500.000,00 (lima ratus ribu rupiah).

6. Sabuk Keselamatan

Tidak Mengenakan sabuk keselamatan. Pasal 289 jo Pasal 106 ayat (6), denda Rp 250.000,00 (dua ratus lima puluh ribu rupiah).

7. Lampu utama Malam hari

Pasal 293 ayat (1), Setiap orang yang mengemudikan Kendaraan Bermotor di Jalan tanpa menyalakan lampu utama pada malam hari dan kondisi tertentu dipidana dengan pidana kurungan paling lama 1 (satu) bulan atau denda paling banyak Rp250.000,00 (dua ratus lima puluh ribu rupiah).

8. Kecepatan maksimum dan minimum

Pasal 287 ayat (5), Setiap orang yang mengemudikan Kendaraan Bermotor di Jalan yang melanggar aturan batas kecepatan paling tinggi atau paling rendah dipidana dengan pidana kurungan paling lama 2 (dua) bulan atau denda paling banyak Rp 500.000,00 (lima ratus ribu rupiah).

9. Berbelok atau berbalik arah

Pasal 294, Setiap orang yang mengemudikan Kendaraan Bermotor yang akan membelok atau berbalik arah, tanpa memberikan isyarat dengan lampu penunjuk arah atau isyarat tangan sebagaimana dimaksud dalam Pasal 112 ayat (1) dipidana dengan pidana kurungan paling lama 1 (satu) bulan atau denda paling banyak Rp 250.000,00 (dua ratus lima puluh ribu rupiah).

10. Melanggar rambu atau marka

Pasal 287 ayat (1), Setiap orang yang mengemudikan Kendaraan Bermotor di Jalan yang melanggar aturan perintah atau larangan yang dinyatakan dengan Rambu Lalu Lintas atau Marka Jalan dipidana dengan pidana kurungan paling lama 2 (dua) bulan atau denda paling banyak Rp 500.000,00 (lima ratus ribu rupiah).

11. Melanggar aturan perintah atau larangan

Pasal 287 ayat (2), Setiap orang yang mengemudikan Kendaraan Bermotor di Jalan yang melanggar aturan perintah atau larangan yang dinyatakan dengan Alat Pemberi Isyarat Lalu Lintas dipidana dengan pidana kurungan paling lama 2 (dua) bulan atau denda paling banyak Rp 500.000,00 (lima ratus ribu rupiah).

12. Hak Pejalan Kaki atau Pesepeda 
Pasal 284, Setiap orang yang mengemudikan Kendaraan Bermotor dengan tidak mengutamakan keselamatan Pejalan Kaki atau pesepeda sebagaimana dimaksud dalam Pasal 106 ayat (2) dipidana dengan pidana kurungan paling lama 2 (dua) bulan atau denda paling banyak Rp 500.000,00 (lima ratus ribu rupiah).

Tolak ukur keberhasilan kegiatan pengabdian ini dilaksanakan dengan mengevaluasi partisipasi peserta penyuluhan. Penyuluhan ini dilaksanakan di SMPN I Lembar dan dihadiri oleh siswa-siswi SMPN I Lembar sebanyak 30 orang siswa dan dibuka oleh kepala sekolah dan seorang guru yang sekaligus sebagai wakil kepala sekolah. Kegiatan ini sangat diapresiasi oleh para guru dan juga para siswa. Hal ini ditunjukkan dengan penyambutan yang sangat terbuka dari Bapak kepala sekolah, para guru dan para siswa.

Keberhasilan dari penyuluhan ini juga ditunjukkan dengan antusiasnya para siswa mendengarkan penjelasan penyuluhan dan juga beberapa orang siswa menanggapi dan bertanya tentang materi yang kurang jelas ataupun yang kurang bisa dipahami oleh siswasiswi. Dari pengamatan yang kami lakukan ada peningkatan kesadaran hukum berlalulintas para pelajar SMPN I Lembar setelah mendengarkan dan mengikuti penyuluhan yang kami laksanakan.

Kegiatan penyuluhan ini diharapkan akan berlanjut dengan dilaksanakannya kegiatan penyuluhan serupa oleh para peserta kepada masyarakat luas di lingkungan pemuda dan pelajar lainnya dengan tingkat yang sama atau lebih tinggi (SMA dan sederajat), sehingga penyebaran informasi isi UU No 22 tahun 2009 tentang pentingnya kesadaran hukum berlalu lintas dapat disambut dengan baik oleh para pelajar dan oleh masyarakat luas sehingga lalu lintas yang tertib bisa menjadi moto hidup masyarakat secara kesuluruhan.

Berikut ini kegiatan yang dilakukan ketika penyuluhan sedang berlangsung dan pada waktu dibuka oleh Bapak kepala sekolah SMPN I Lembar

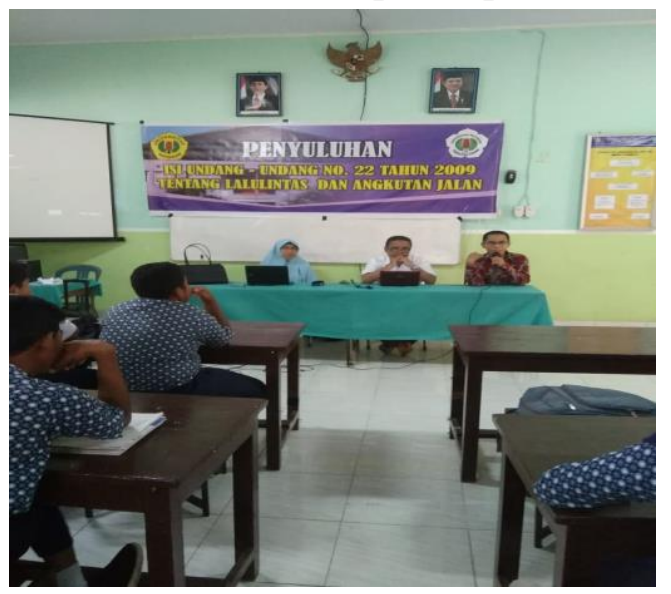

Gambar 1. Pak Kepala Sekolah membuka 2019 dan memberiakn pengarahan sebelum penyuluhan dimulai

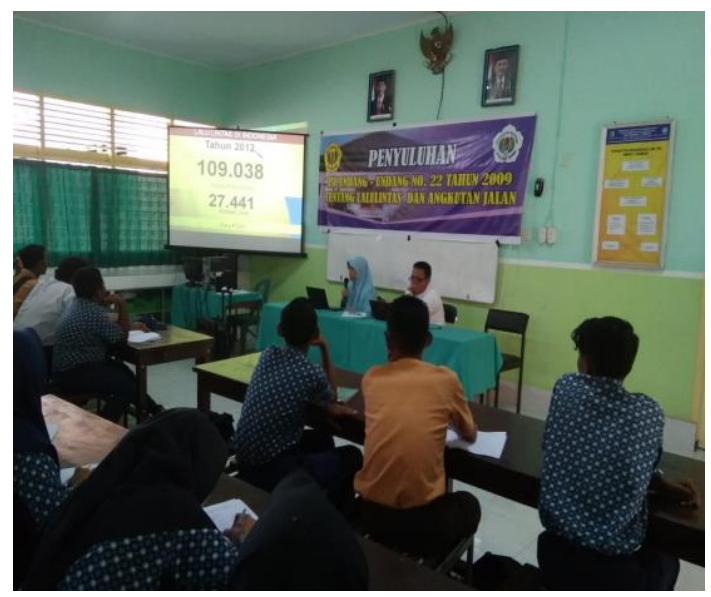

Gambar 2. Penyuluhan isi UU No. 22 th 

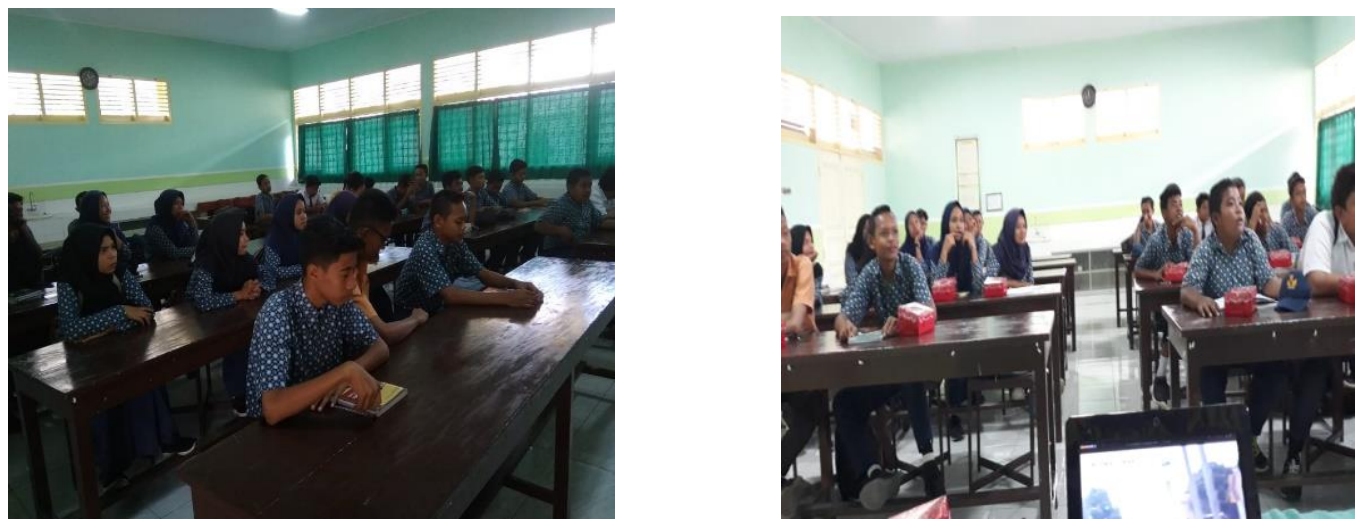

Gambar 3. Para siswa-siswi mendengarkan penjelasan materi penyuluhan dengan penuh semangat
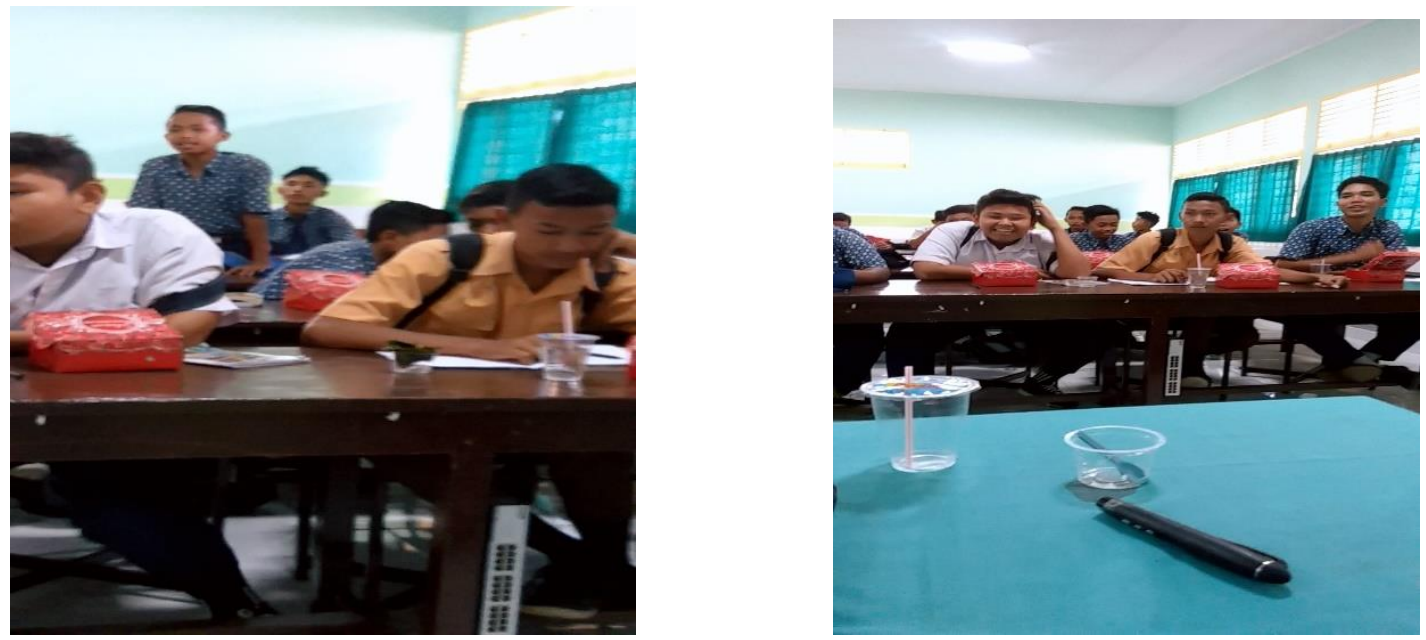

Gambar 4. Para siswa siswi memberikan tanggapan dan bertanya materi penyuluhan yang belum dipahami

\section{KESIMPULAN:}

\section{KESIMPULAN DAN SARAN}

Berdasarkan hasil analisa dan pembahasan dari penyuluhan isi UU No. 22 tentang lalu lintas dan angkutan jalan yang telah dilakukan di SMPN I Lembar maka dapat diambil kesimpulan sebagai berikut :

1. Penyuluhan ini mendapat penerimaan yang sangat terbuka dari Bapak kepala sekolah, para guru dan para siswa.

2. Dengan adanya penyuluhan ini terjadi peningkatan kesadaran hukum berlalulintas para pelajar SMPN I Lembar

\section{SARAN:}

Berdasarkan kesimpulan yang telah diuraikan di atas, maka penulis menyarankan supaya dilaksanakannya kegiatan penyuluhan serupa kepada masyarakat luas di lingkungan pemuda dan pelajar lainnya dengan tingkat yang sama atau lebih tinggi (SMA dan sederajat), atau pada SMP dan sederajat di Kabupaten Lombok Barat. 


\section{UCAPAN TERIMA KASIH}

Dengan selesainya penyuluhan yang dilakukan di SMPN I Lembar tidak lupa kami ucapkan terima kasih yang sebesar-besarnya terutama kepada:

1. Bapak Dekan Fakultas Teknik yang telah menugaskan kami untuk melaksanakan pengabdian kepada masyarakat yang bertempat di SMPN I Lembar.

2. Bapak Kepala Sekolah SMPN I Lembar yang telah memberikan izin kepada kami untuk melaksakan penyuluhan di SMPN I Lembar.

3. Bapak/Ibu guru SMPN I Lembar yang telah ikut membantu sehingga penyuluhan ini bisa berlangsung dengan baik dan sesuai dengan rencana.

4. Para siswa-siswi SMPN I Lembar yang dengan senang hati dan sabar mendengarkan penjelasan dari materi penyuluhan yang kami lakukan.

5. Dan semua pihak yang telah membantu sehingga penyuluhan ini bisa terlaksana.

\section{DAFTAR PUSTAKA}

Morlok, Edwar., K 1995. Pengantar Teknik Dan Perencanaan Transportasi, Jakarta, Erlangga.

Peraturan Pemerintah Nomor 41 tahun 1993 Tentang Angkutan Jalan.

Salim Abbas, 2002, Manajemen Transportasi, PT Raja Grafindo, Jakarta

Suteja W., 2000, Studi Karakteristik Sistem Angkutan Umum di Kotamadya Mataram, Jurnal

Transportasi FSTPT, Vol 2 Nomor 1 tahun I, Juni 2002, Jakarta

Tamin, Ofyar., Z., 2008, Perencanaan, Pemodelan dan Rekayasa Transportasi, Bandung, ITB.

Undang-Undang Nomor 14 Tahun 1992 tentang Lalu Lintas dan Angkutan Jalan 